\title{
A panoramic spectrum of complex interplay between the immune system and IL-32 during pathogenesis of various systemic infections and inflammation
}

\author{
Babar Khawar ${ }^{1}$, Muddasir Hassan Abbasi ${ }^{1,2}$ and Nadeem Sheikh ${ }^{1 *}$
}

\begin{abstract}
Cytokines have always been of great interest due to their vast potential and participation in the progression and pathogenesis of various ailments. Interleukin-32 (IL-32) is a recently identified cytokine, whose gene is located on human chromosome 16 p13.3, with eight exons and six splice variants (IL-32a to IL-32Z). IL-32a, the most abundant form, is secreted by different types of cells including T cells, natural killer (NK) cells, monocytes, endothelial cells and epithelial cells. It acts as a preferential mediator and effector of abnormal immune responses to multiple inflammatory and auto immune diseases including rheumatoid arthritis, chronic obstructive pulmonary disease (COPD), inflammatory bowel disease (IBD), etc. It was found to stimulate the induction of various chemokines, pro-inflammatory cytokines including IL-1 $\beta, I L-6, I L-8$, TNF- $\alpha$ and macrophage inflammatory protein-2 (MIP-2). Hence, IL-32 mediates the crucial interplay among immune system and body cells during pathogenesis of various insults. The aim of the present effort is to summarize the role, mechanism of pathogenesis and potential therapeutic applications of IL-32 in different systemic infections and diseased conditions.
\end{abstract}

Keywords: Auto immune disease, Inflammatory bowel disease, Interleukin-32, Rheumatoid arthritis

\section{Introduction}

Cytokines are small, pleiotropic, nonstructural soluble factors (probably polypeptides/proteins) with molecular weights ranging between 8 to 40,000 Da. Every cell is capable of producing cytokines and can respond to them. Cytokines are principally involved in homeostatic mechanisms by mediating and regulating inflammatory/ immune responses to various insults like diseased conditions or infections and affect cellular interactions and cell communication system. These peptides could be autocrine, paracrine and perhaps even endocrine regarding their site of action $[1,2]$. These are principally classified into various classes on the basis of their biological roles. The term cytokines includes lymphokines, monokines, chemokines and interleukins made and secreted by a variety of immune system components, specifically, lymphocytes, monocytes

\footnotetext{
*Correspondence: s_nadeem77@yahoo.com

${ }^{1}$ Cell and Molecular Biology Lab, Department of Zoology, University of the

Punjab, Quaid-e-Azam Campus, Lahore, Pakistan

Full list of author information is available at the end of the article
}

and leukocytes. The aim of the current review is to emphasize the existing therapeutic potential and future perspective of interleukin-32 (IL-32). The extraordinary qualities of this interleukin have prompted their application in the field of medical biology.

Interleukin-32 (IL-32), a recently described cytokine (previously called natural killer cell transcript 4 (NK4)), found originally as a transcript that is in a cDNA library derived from IL-2 activated natural killer cells [3], as well as being expressed selectively in T-lymphocytes, monocytes and epithelial cell lines [4-6]. It is an important player in innate and adaptive immune responses in vitro [4], and its production is predominantly induced by IL- $1 \beta$, TNF- $\alpha$, IL- 2 or IFN- $\gamma$ in blood monocytes and epithelial cells $[3,5,7]$. IL-32 is a pleiotropic cytokine that is involved in number of biological functions including cell differentiation [8-10], stimulation of pro- or anti-inflammatory cytokines [11-13] and cell death, especially apoptosis (Figure 1) [14,15]. 


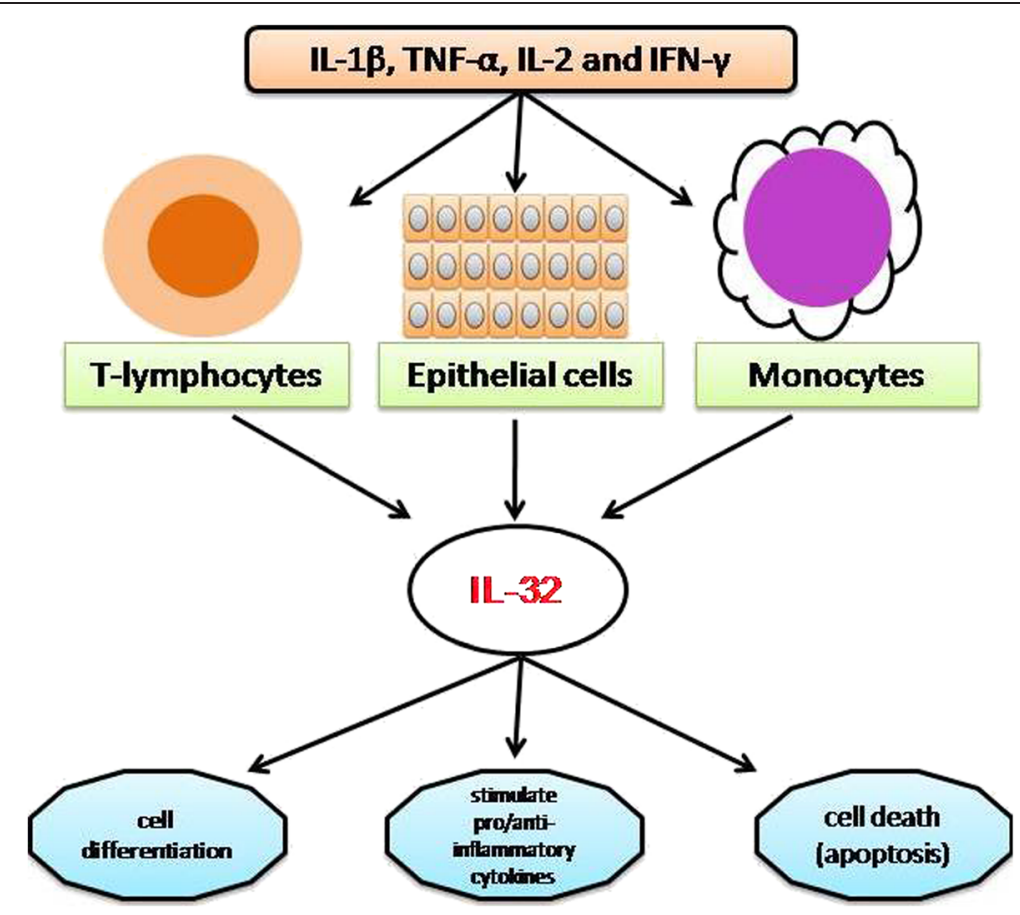

Figure 1 Production of IL-32 by various body cells, namely, epithelial cell lines, T-lymphocytes and monocytes, and its involvement in different cellular processes including cell differentiation and cell death, as well as interactions with the immune system.

\section{Review}

Human recombinant IL-32 does not exhibit similarities with known cytokine families, yet several properties are typical of a pro-inflammatory cytokine $[5,16,17]$. It was discovered accidently while studying the genes induced by IL-18 and was found to stimulate the production of various chemokines, pro-inflammatory cytokines including IL-1 $\beta$, IL-6, IL-8, TNF- $\alpha$ and macrophage inflammatory protein-2 (MIP-2) $[5,10,17,18]$.

Inflammation or infection with various pathogens including Mycobacterium tuberculosis, Epstein-Barr virus (EBV), human immunodeficiency virus (HIV) and influenza A virus have been reported to induce the expression of IL-32 [19-22]. The IL-32 gene is located on human chromosome $16 \mathrm{p} 13.3$, which is organized into eight exons with six splice variants of the gene; these variants have been described as IL-32 $\alpha$, IL-32 $\beta$, IL-32 $\gamma$,

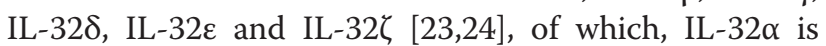
the most abundant transcript [25].

Anti-tumor activity of NK cells is provoked by IL-12 and IL-18, both of which induce IL-32 production that stimulates TNF- $\alpha$ synthesis enhancing NK apoptotic activity $[3,5,6,26]$. IL-32 was found in cytosol as well as in the nucleus. Park et al. [27] reported that IL-32 enhances the anti-tumor activity specifically for NK-92 cells upon introduction of the death receptor and the activation of caspase-3 pathway in cancer cells.
IL-32 has been reported to play a key role in the pathogenesis of various disorders, including infectious autoimmune and inflammatory diseases.

\section{IL-32 in rheumatoid arthritis}

Rheumatoid arthritis (RA) is a chronic autoimmune disease that is often associated with inflammation and joint destruction, which ultimately results in significant disability. Cagnard et al. [28] reported an elevation in IL-32 expression in patients with rheumatoid arthritis (RA) in contrast to osteoarthritis [28], and the severity of the symptoms was found to be correlated with high degree of expression of TNF- $\alpha$, a potent inducer of IL-32 mRNA expression in human synovial fibroblasts. Overexpression of IL-32 in turn stabilized the mRNA transcripts of other cytokines, namely, those for TNF- $\alpha$, IL- $1 \beta$ and IL-8.

In another study on anti-TNF- $\alpha$ treatment in patients with RA, synovial knee biopsies showed a significant decrease in IL-32 expression [11]. Similarly, human IL-32 leads to joint swelling and recruitment of inflammatory cells, along with cartilage derangements, when injected in joints of naïve mice. In contrast, in a TNF- $\alpha$ deficient mice model, joint swelling and influx of inflammatory cells have been drastically decreased (Figure 2) [22]. 


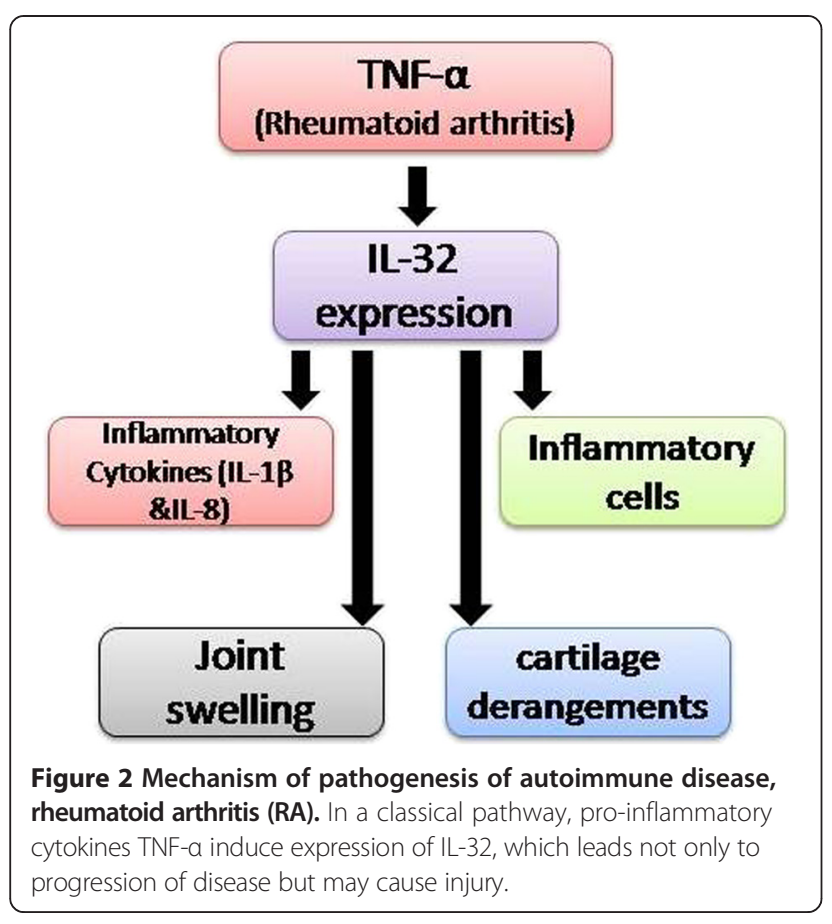

In a study to explore the role of IL-32 in RA, CD14 ${ }^{+}$ monocytes and synovial tissue were analyzed from healthy volunteers and RA patients. The IL-32 $\gamma$ level was found significantly upregulated in RA patients in accordance with results of an experimental model of inflammatory arthritis in mice in which the administration of IL-32 aggravated disease conditions $[8,29,30]$. Synergism between the soluble receptor activator of nuclear factor $\mathrm{\kappa}-\mathrm{B}$ ligand (sRANKL) and IL-32 $\gamma$ was demonstrated. In IL-32 $\gamma$ treated cultures, the presence of sRANKL aggravates the activity of osteoclasts, as well as increases the resorption of tissues, compared to IL-17 [8]. Presence of significantly high levels of IL-32 in synovial tissue biopsies of RA as compared to its absence in osteoarthritic (OA) patients confirmed that IL-32 is potent mediator of the active osteoclastogenic activity [22]. This extraordinary interleukin was also found to be involved in the release of prostaglandin E2 from human blood monocytes and mouse macrophages. IL-32 mediated cell influx and joint swelling was found to be reduced in TNF $\alpha$-deficient mice, which suggest that the expression of this cytokine is TNFo-dependent in RA [22]. The signal pathway of TNF $\alpha$-dependent mediation of IL-32 expression in RA was explored by Moon et al. They reported the involvement of spleen tyrosine kinase (Syk)/ protein kinase $C \delta$ (PKC $\delta$ )/c-Jun N-terminal kinase (JNK) pathways in the regulation of IL-32 induction by TNF- $\alpha$ in synovial fibroblasts [29]. An upregulated level of IL-32 was found in cases of RA fibroblast-like synoviocytes (FLS), while it was absent in biopsies of OA. This increased level of IL-32 was found to be suppressed by small interfering
RNA (siRNA) of these enzymes as well as by the inhibitors of PKCS, Syk and JNK. Recent research has revealed the key role of FLS in osteoclastic activity, as well as their role in pannus formation in joints [31]. Various factors and interactions such as cell-to-cell contacts, pathogen-associated molecular patterns (PAMPs), pattern-recognition receptors (PRRs), and cytokine environment, along with damageassociated molecular patterns (DAMPs), may be involved in the activation of FLS. Lipopolysaccharide (LPS), peptidoglycan and some other bacterial products have also been reported, which result in the activation of FLS activity by interacting with PRRs of these cells $[32,33]$. FLSs, in response to inflammatory stimuli, expressed a large number of PRRs, especially TLR2, TLR3 and TLR4, $[34,35]$. FLS-induced inflammatory response is mediated by synthesizing a variety of cytokines, prostanoids, chemokines, and nitric oxide (NO) [31]. TNF- $\alpha$, IFN- $\gamma$, and PAMPS have been reported to regulate the secretion of IL-6, IL-8, and B-cell-activating factor by FLS [36,37]. IL-32 and IL-17 are two major inflammatory cytokines, which together are thought to play a similar role and synergistically involved in differentiation of osteoclasts. A few new genes that is, CXC chemokine receptor 4 (CXCR4), IL-32 and lamina propria lymphocytes (LPL) were confirmed due to expression of IL-17A and IL-17 F in combination with TNF- $\alpha$ in RA synoviocytes [38]. $\mathrm{CD}_{4}{ }^{+} \mathrm{T}$ cells or dendritic cells and RA FLSs have been previously employed in various studies to reveal a reciprocal interaction between IL-32 and TNF- $\alpha$ depicting a TNF- $\alpha / \mathrm{IL}-32 / \mathrm{TNF}-\alpha$-positive auto-inflammatory loop [11]. Anti-TNF- $\alpha$ treatment of RA patients has resulted in a significant reduction of IL-32 peptides in synovial tissue [11]. Recently, IL-32 g was reported to be involved in maturation and activation of immature dendritic cells (DCs), along with an increased Th1 and Th17 response by IL-12 and IL-6 [39]. Both IL-17 and IL-32 influence pathogenesis by TNF-R1 dependent/independent pathway by employing p300 and death-associated protein kinase 1 (DAPK-1) [40]. IL-32 and IL-17 can augment osteoclastogenesis by RANKL-dependent manner, as well as reciprocally affect each other's production in RA synovium.

IL-32 $\beta, \delta$, and $\gamma$ mRNA overexpression in RA FLS is primarily induced by TNF- $\alpha$, IFN- $\gamma$ and toll-like receptor (TLR)-2, -3 , and -4 ligands [41]. Mature IL-32 is expressed by various cells of the body due to intracellular polyriboinosinic polyribocytidylic acid (poly I:C) and TNF- $\alpha$.

The overexpression of IL-32 in a number of diseases including asthma, inflammatory bowel disease (IBD) and RA has been reported to be induced by IL-18 [5].

\section{IL-32 in inflammatory bowel disease}

Inflammatory bowel disease (IBD), a chronic and degenerating inflammatory disorder of the gastrointestinal tract 
(GIT), has two common forms: ulcerative colitis (UC) and Crohn's disease (CD). The pathogenesis of disease has been found to be associated with following common symptoms: mild fever, abdominal pain, chronic diarrhea, and ulceration of colon/ rectum often resulting in rectal bleeding. In the case of $\mathrm{CD}$, stenosis, fistulation, and abscesses may be sometimes associated with former symptoms, while in case of UC an additional problem megacolon has been reported. Currently, the exact mechanism involved in IBD is mysterious currently but role of unidentified components of gut microflora has been an established view in an abnormal cascade of inflammatory responses during this disease [42-46]. Netea et al. [17] found that a bacterial peptidoglycan (muramyl dipeptide) induced the expression of IL-32 with the nucleotide-binding oligomerization domaincontaining protein 1 (NOD1) and the nucleotide-binding oligomerization domain-containing protein 2 (NOD2) through a caspase-1-dependent mechanism that ultimately induces activation of the nuclear factor kappalight-chain-enhancer of activated B cells (NF-kB) and augments the production of IL-1 $\beta$ and IL-6 [17,47]. Recently, Crohn's disease (CD) patients have been found to have an enhanced IL- $1 \beta$ and NF- $\mathrm{kB}$ activity due to mutation in NOD2. All of the above findings confirmed a key role of IL-32 in the progression and pathophysiology of IBD, especially in CD $[48,49]$. IL-32 and TNF- $\alpha$ seems to play a role in the pathogenesis of IBD, as IL-32 is found to be overexpressed in an amplified manner along with TNF- $\alpha$ (Figure 3) [25].

A new isoform of IL-32 has been identified in human colonic subepithelial myofibroblasts (SEMFs); this isoform lacks exon 3 and 4 of the IL-32 $\gamma$ isoform (longest isoform) and was named as IL-32 $\varepsilon$ [50]. An enhanced level of the transcript of IL-32 $\varepsilon$ was found in inflamed mucosa of IBD patients. TNF- $\alpha$, in a time- and dosedependent manner, was found to be an active inducer of transcript of this new IL-32 $\varepsilon$ [50]. It has been reported previously in a study in HT-29 cells, that transfection of IL-32 $\varepsilon$ results in an overall decrease of IL- 8 transcript mediated by TNF $\alpha$, but the expression of the shortest isoform IL-32 $\alpha$, which lacks exon 3 and 7, showed no effect on the IL-8 transcript. In vivo experiments were inspected to find out the role of IL-32 in intestinal inflammation by using an IL-32 $\gamma$ transgenic mouse (IL-32 $\gamma$-TG) that expressed human IL-32 $\gamma$. Considerable amounts of TNF- $\alpha$ were reported in the sera and colonic tissue of IL-32 $\gamma$-TG mice while the mice remain healthy. Because of this enhanced pro-inflammatory cytokine, IL-32 $\gamma$-TG exhibited a slightly early and greater acute inflammation as compared to wild type mice upon the dextran sodium sulfate (DSS)-induced colitis. Nevertheless, there is a lesser amount of colonic inflammation and better survival rate compared with wild-type mice after day 6 . The colonic

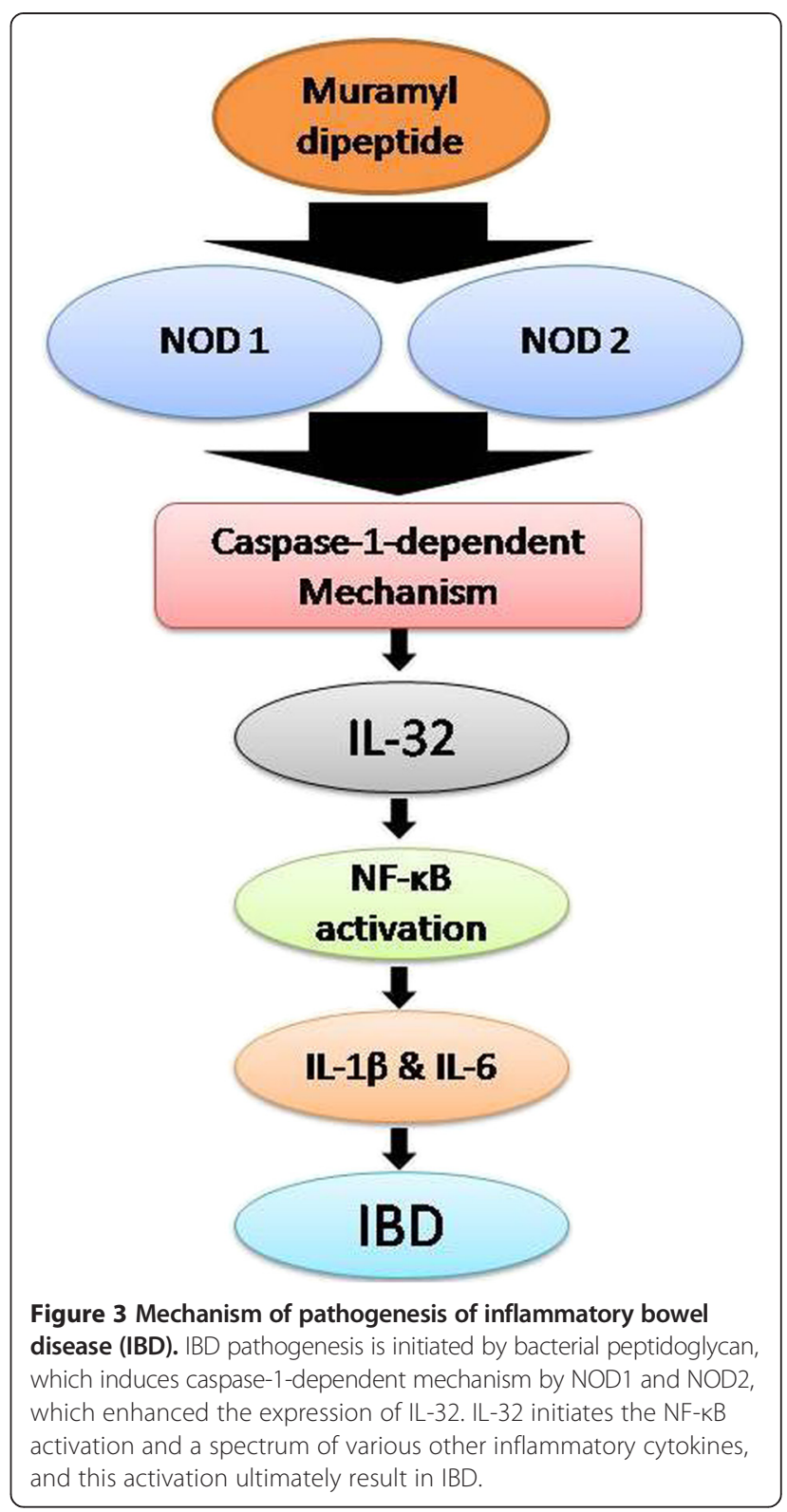

level of inflammatory cytokine related to attenuated tissue damage was significantly decreased in IL-32 $\gamma$-TG-treated with DSS and the constitutive level of IL-32 $\gamma$ in colonic tissue was also decreased [51]. So conclusions can be drawn on how IL-32 $\gamma$ enhances the innate inflammation, as well as how it protects intestinal integrity.

IL-32 not only stimulates the production of various inflammatory cytokines with monocytes but also causes monocytes to differentiate into macrophage or dendritic cells (DCs) [10]. IL-32 stimulates neutrophils directly to produces IL-6 and IL-8 [8,51,52]. These differentiated macrophages and DCs are potent source of some very crucial inflammatory cytokines, that is, TNF- $\alpha$, IL- $1 \beta$, and IL-6, which recruit T-cells in the inflamed area in 
cases of IBD and CD. Differentiated DCs help in the proliferation of these T-cells to protect the host against the invading pathogens. This increase in the numbers of various immune cells without proper immune suppressor molecules leads to infiltration of neutrophils in an inflamed area, which results in the release of a variety of neutrophil proteinases such as cathepsin G, elastase, and proteinase 3 (PR3). These enzymes of serine proteinase family are powerful mediators of mucosal tissue injury exacerbating inflammation in CD and IBD. Though expression of IL-32 is elevated in the epithelial cells of inflamed mucosa from IBD and CD patients the biological role of IL-32 in vivo and in vitro was inconsistent. Eight different IL-32 mRNA transcripts give rise to five IL-32 isoforms (Kim S, 2014 unpublished data). The divergence of in vitro and in vivo data could be because of the fact that each researcher has studied a different IL-32 isoform.

In one study, the level of mRNA transcript and IL-32 $\alpha$ protein was found to be significantly high in the IBD patients with inflamed epithelial mucosa compared to normal individuals [48]. Further studies suggested that IL-32 interacts with various other cytokines including IL-1 $\beta$, TNF- $\alpha$ and IFN $\gamma$ and plays an important role in pathophysiology of IBD and CD [53-55]. There is a need of further studies to evaluate the precise role of IL-32 in IBD and CD.

\section{IL-32 in chronic obstructive pulmonary disease}

Chronic obstructive pulmonary disease (COPD) is currently one of the leading causes of morbidity and mortality globally. COPD is a progressive disease occurring as an inflammatory response to toxic particles or gases [56], and careful estimates predict that it will be the third major cause of death by the year 2020. COPD lessens the quality of life, causes frequent hospital admissions, and ultimately enhances the risk of death [57-59]. In the US alone, the annual costs of COPD are approximately $\$ 50$ billion, and most of these costs are due to exacerbations requiring hospitalization. The etiology of COPD points toward the interactions between genetic factors and various environmental factors, predominantly cigarette smoking [60]. More than $90 \%$ of cases of COPD currently are due to chronic cigarette smoking in westernized countries, which sets off an inflammatory response in peripheral lung tissues as well as in the larger bronchi. But a number of recent studies have reported a significant prevalence of COPD among non-smokers and those who have never smoked. Various studies have reported the persistence of chronic inflammation throughout the airways, pulmonary vasculature, lung parenchyma, and even outside the lungs [61,62]. A variety of factors, including the environmental indoor pollution because of use of biomass fuel consumption and coal, may be important causes of it $[56,63,64]$. COPD is characterized by constriction and obstruction of air passage ways and continual inflammation in pulmonary parenchymal tissues $[57,65,66]$. This inflammatory process is much pronounced and persistent even after quitting smoking in those susceptible smokers who develop COPD. The pathogenic mechanisms of this inflammation are not fully understood yet but various researchers have reported macrophages, T cells, and neutrophils as being important players [18,66-72]. The major inflammatory mediators in the progression of COPD were found to be respiratory epithelial cells. Multiple factors including smoking, infection and proteases have been reported by numerous researchers to be involved in the activation of airway epithelial cells in COPD [66,73-75]. These activated cells secrete a vast array of molecules prominently growth factors (GM-CSF and TGF- $\beta$ ), inflammatory cytokines (TNF- $\alpha$, some members of IL-7 family and IL-12) and chemokines (CCL2, CXCL5, and CXCL10) [65,76,77]. Interferon gamma (IFN- $\gamma$ ) induces IL-32 expression in monocytes and epithelial cells, which through the activation of two key pathways, namely, NF-kB and p38 MAPK, results in the induction of an array of other proinflammatory cytokines and chemokines, including TNF- $\alpha$, IL- 8 and MIP-2 [5], which are involved in the disease progression in COPD patients. Calabrese et al. [78] were the first to report the effect of IL-32 in COPD-affected smokers. For this purpose, smokers with COPD were compared with non-COPD smokers and nonsmokers. The expression of IL-32 in lung tissue of COPD patients was found to be increased and correlated with the degree of airflow obstruction in vivo. IL-32/ TNF- $\alpha$ was suggested to play a key role in the progression of the immune response in COPD inflammation. Marked increased in IL-32 expression clearly showed role of IL-32 in the enhancement of the immune response in COPD, with a possible impact on disease progression . Kudo et al. [79] reported an increase in the expression of IL-32 due to oxidative stress $\left(\mathrm{H}_{2} \mathrm{O}_{2}\right)$ and inflammation in human bronchial epithelial cells. A significant increase in IL-32 expression in lung samples and plasma of a similar cohort of COPD patients has been reported $[78,80]$.

\section{Conclusions}

Recently, the complex crosstalk between the immune system and IL-32 has become a topic of hot debate. From above data, it could be concluded that IL-32 is a key player, which exerts its biological functions intracellularly, inducing the expression of various pro-inflammatory cytokines and, hence, contributing to the progression and pathogenesis of various diseased conditions and systemic infections. Despite the recent progress, a lot of hidden potentials and features of this mysterious cytokine remain to be revealed. Currently, it is a challenge to understand 
the balance between its beneficial and pathological roles after administration or inhibition of this critical cytokine. However, the current status of research indicates a wide therapeutic potential of IL-32 in the medical area, in the near future.

\section{Abbreviations}

FLS: fibroblast-like synoviocytes; GIT: gastrointestinal tract; HIV: human immunodeficiency virus; IBD: inflammatory bowel disease; IL: interleukin; IL-32: interleukin-32; JNK: c-Jun N-terminal kinase; LPS: lipopolysaccharide; MIP-2: macrophage inflammatory protein-2; NF-KB: nuclear factor kappa-light-chain-enhancer of activated B cells; NK4: natural killer cell transcript 4; NOD: nucleotide-binding oligomerization domain-containing protein; OA: osteoarthritis; PAMPs: pathogen-associated molecular patterns; PKC : protein kinase C $\delta$; poly l:C: polyriboinosinic polyribocytidylic acid; PRRs: pattern-recognition receptors; PR3: proteinase 3; RA: rheumatoid arthritis; SEMFs: subepithelial myofibroblasts; SRANKL: soluble receptor activator of nuclear factor K-B ligand; Syk: spleen tyrosine kinase; TLR: toll-like receptor; UC: ulcerative colitis.

\section{Competing interests}

The authors declare that they have no competing interests.

\section{Authors' contributions}

BK provided the concept and participated in the study design, data collection and manuscript preparation. MHA was involved in trouble shooting suggestions. NS supervised the manuscript draft and approved the final manuscript. All authors read and approved the final manuscript.

\section{Acknowledgements}

The authors are thankful to the Ph.D Scholar Ms. Tasleem Akhtar at the Cell and Molecular Biology Lab, Department of Zoology, University of the Punjab, Lahore, Pakistan for providing moral support for the accomplishment of this review.

\section{Author details}

${ }^{1}$ Cell and Molecular Biology Lab, Department of Zoology, University of the Punjab, Quaid-e-Azam Campus, Lahore, Pakistan. ${ }^{2}$ Department of Zoology, Governments. College of Science, Wahdat Road, Lahore, Pakistan.

Received: 17 November 2014 Accepted: 2 January 2015

Published online: 28 January 2015

\section{References}

1. Navarro-Gonzalez JF, Mora-Fernandez C. The role of inflammatory cytokines in diabetic nephropathy. J Am Soc Nephrol. 2008;19:433-42.

2. Dinarello CA. Proinflammatory cytokines. Chest J. 2000;118:503-8.

3. Dahl CA, Schall RP, He HL, Cairns JS. Identification of a novel gene expressed in activated natural killer cells and T cells. J Immunol. 1992;148:597-603.

4. Chomczynski P, Sacchi N. The single-step method of RNA isolation by acid guanidinium thiocyanate-phenol-chloroform extraction: twenty-something years on. Nat Protoc. 2006;1:581-5.

5. Kim SH, Han SY, Azam T, Yoon DY, Dinarello CA. Interleukin-32: a cytokine and inducer of TNF-alpha. Immunity. 2005;22:131-42.

6. Shoda H, Fujio K, Yamaguchi Y, Okamoto A, Sawada T, Kochi Y, et al. Interactions between IL-32 and tumor necrosis factor alpha contribute to the exacerbation of immune-inflammatory diseases. Arthritis Res Ther. 2006;8:R166

7. Marian E, Baraldo S, Visentin A, Papi A, Saetta M, Fabbri LM, et al. Up-regulated membrane and nuclear leukotriene B4 receptors in COPD. Chest J. 2006;129:1523-30.

8. Kim YG, Lee CK, Oh JS, Kim SH, Kim KA, Yoo B. Effect of interleukin-32-gamma on differentiation of osteoclasts from CD14+ monocytes. Arthritis Rheum. 2010;62:515-23.

9. Mabilleau G, Sabokbar A. Interleukin-32 promotes osteoclast differentiation but not osteoclast activation. PLoS One. 2009:4:e4173.

10. Netea MG, Lewis EC, Azam T, Joosten LA, Jaekal J, Bae SY, et al. Interleukin-32 induces the differentiation of monocytes into macrophage-like cells. Proc Natl Acad Sci. 2008;105:3515-20.
11. Heinhuis B, Koenders MI, van Riel PL, van de Loo FA, Dinarello CA, Netea $M G$, et al. Tumour necrosis factor alpha-driven IL-32 expression in rheumatoid arthritis synovial tissue amplifies an inflammatory cascade. Ann Rheum Dis. 2011;70:660-7.

12. Heinhuis B, Koenders MI, van de Loo FA, Netea MG, van den Berg WB, Joosten LA. Inflammation-dependent secretion and splicing of IL-32-gamma in rheumatoid arthritis. Proc Natl Acad Sci. 2011;108:4962-7.

13. Kang J-W, Choi S-C, Cho M-C, Kim H-J, Kim J-H, Lim J-S, et al. A proinflammatory cytokine interleukin 32-Beta promotes the production of an anti-inflammatory cytokine interleukin - 10. Immunology. 2009;128:e532-40.

14. Goda C, Kanaji T, Kanaji S, Tanaka G, Arima K, Ohno S, et al. Involvement of IL-32 in activation-induced cell death in T cells. Int Immunol. 2006;18:233-40.

15. Meyer N, Zimmermann M, Burgler S, Bassin C, Woehrl S, Moritz K, et al. IL-32 is expressed by human primary keratinocytes and modulates keratinocyte apoptosis in atopic dermatitis. J Allergy Clin Immunol. 2010;125:858-65.

16. Maestrelli P, El Messlemani Ah, De Fina O, Nowicki Y, Saetta M, Mapp C, et al. Increased expression of heme oxygenase ( $\mathrm{HO})-1$ in alveolar spaces and HO-2 in alveolar walls of smokers. Am J Respir Crit Care Med. 2001;164:1508-13.

17. Netea MG, Azam T, Ferwerda G, Girardin SE, Walsh M, Park JS, et al. IL-32 synergizes with nucleotide oligomerization domain (NOD) 1 and NOD2 ligands for IL-1Beta and IL-6 production through a caspase 1-dependent mechanism. Proc Natl Acad Sci U S A. 2005;102:16309-14.

18. Saetta M, Baraldo S, Corbino L, Turato G, Braccioni F, Rea F, et al. CD8+ ve cells in the lungs of smokers with chronic obstructive pulmonary disease. Am J Respir Crit Care Med. 1999;160:711-7.

19. Li W, Sun W, Liu L, Yang F, Li Y, Chen Y, et al. IL-32: a host proinflammatory factor against influenza viral replication is upregulated by aberrant epigenetic modifications during influenza A virus infection. J Immunol. 2010;185:5056-65.

20. Nold MF, Nold-Petry CA, Pott GB, Zepp JA, Saavedra MT, Kim SH, et al. Endogenous IL-32 controls cytokine and HIV-1 production. J Immunol. 2008;181:557-65.

21. Netea MG, Azam T, Lewis EC, Joosten LA, Wang M, Langenberg $D$, et al. Mycobacterium tuberculosis induces interleukin-32 production through a caspase-1/LL-18/interferon-gamma-dependent mechanism. PLoS Med. 2006;3:e277.

22. Joosten LA, Netea MG, Kim SH, Yoon DY, Oppers-Walgreen B, Radstake TR, et al. IL-32, a proinflammatory cytokine in rheumatoid arthritis. Proc Natl Acad Sci U S A. 2006;103:3298-303.

23. Ferlazzo G, Pack M, Thomas D, Paludan C, Schmid D, Strowig T, et al. Distinct roles of IL-12 and IL-15 in human natural killer cell activation by dendritic cells from secondary lymphoid organs. Proc Natl Acad Sci U S A. 2004;101:16606-11.

24. Screpanti V, Wallin R, Grandien A, Ljunggren HG. Impact of FASL-induced apoptosis in the elimination of tumor cells by NK cells. Mol Immunol. 2005; $42: 495-9$

25. Nold-Petry CA, Nold MF, Zepp JA, Kim SH, Voelkel NF, Dinarello CA. IL-32 dependent effects of IL-Beta on endothelial cell functions. Proc Natl Acad Sci. 2009;106:3883-8.

26. Dinarello CA, Kim SH. IL-32, a novel cytokine with a possible role in disease. Ann Rheum Dis. 2006; 65:iii61-4.

27. Park MH, Song MJ, Cho M, Moon DC, Yoon DY, Han SB, et al. Interleukin-32 enhances cytotoxic effect of natural killer cells to cancer cells via activation of death receptor 3. Immunology. 2012;135:63-72.

28. Cagnard N, Letourneur F, Essabbani A, Devauchelle VR, Mistou S, Rapinat A, et al. Interleukin-32, CCL2, PF4F1 and GFD10 are the only cytokine/chemokine genes differentially expressed by in vitro cultured rheumatoid and osteoarthritis fibroblast-like synoviocytes. Eur Cytokine Netw. 2005;16:289-92.

29. Moon YM, Yoon BY, Her YM, Oh HJ, Lee JS, Kim KW, et al. IL-32 and IL-17 interact and have the potential to aggravate osteoclastogenesis in rheumatoid arthritis. Arthritis Res Ther. 2012;14:R246.

30. Xu WD, Zhang M, Feng CC, Yang XK, Pan HF, Ye DQ. IL-32 with potential insights into rheumatoid arthritis. Clin Immunol. 2013;147:89-94.

31. Muller-Ladner U, Gay S. The role of fibroblast-like synoviocytes in rheumatoid arthritis. Rheumatoid Arthritis. 2006;2:107-21.

32. Pierer M, Rethage J, Seibl R, Lauener R, Brentano F, Wagner U, et al. Chemokine secretion of rheumatoid arthritis synovial fibroblasts stimulated by Toll-like receptor 2 ligands. J Immunol. 2004;172:1256-65. 
33. Jung YO, Cho ML, Kang CM, Jhun JY, Park JS, Oh HJ, et al. Toll-like receptor 2 and 4 combination engagement upregulate IL-15 synergistically in human rheumatoid synovial fibroblasts. Immunol Lett. 2007;109:21-7.

34. Kyburz D, Rethage J, Seibl R, Lauener R, Gay RE, Carson DA, et al. Bacterial peptidoglycans but not CpG oligodeoxynucleotides activate synovial fibroblasts by toll-like receptor signaling. Arthritis Rheum. 2003;48:642-50.

35. Ospelt C, Brentano F, Rengel Y, Stanczyk J, Kolling C, Tak PP, et al. Overexpression of toll-like receptors 3 and 4 in synovial tissue from patients with early rheumatoid arthritis: Toll-like receptor expression in early and longstanding arthritis. Arthritis Rheum. 2008:58:3684-92.

36. Alsaleh G, Messer L, Semaan N, Boulanger N, Gottenberg J-E, Sibilia J, et al. BAFF synthesis by rheumatoid synoviocytes is positively controlled by alpha 5-beta1 integrin stimulation and is negatively regulated by tumor necrosis factor-alpha and toll-like receptor ligands. Arthritis Rheum. 2007;56:3202-14.

37. Ohata J, Zvaifler NJ, Nishio M, Boyle DL, Kalled SL, Carson DA, et al. Fibroblast-like synoviocytes of mesenchymal origin express functional $B$ cell-activating factor of the TNF family in response to proinflammatory cytokines. J Immunol. 2005;174:864-70.

38. Zrioual S, Ecochard R, Tournadre A, Lenief $V$, Cazalis MA, Miossec $P$. Genome-wide comparison between IL-17A-and IL-17 F-induced effects in human rheumatoid arthritis synoviocytes. J Immunol. 2009:182:3112-20.

39. Jung MY, Son MH, Kim SH, Cho D, Kim TS. IL-32gamma induces the maturation of dendritic cells with Th1-and Th17-polarizing ability through enhanced IL-12 and IL-6 production. J Immunol. 2011;186:6848-59.

40. Turner-Brannen E, Choi KYG, Arsenault R, El-Gabalawy H, Napper S, Mookherjee N. Inflammatory cytokines IL-32 and IL-17 have common signaling intermediates despite differential dependence on TNF-receptor 1. J Immunol. 2011;186:7127-35.

41. Alsaleh G, Sparsa L, Chatelus E, Ehlinger M, Gottenberg JE, Wachsmann D, et al. Research Article Innate Immunity Triggers IL-32 Expression By Fibroblast-Like Synoviocytes In Rheumatoid Arthritis. 2010.

42. Xavier RJ, Podolsky DK. Unravelling the pathogenesis of inflammatory bowel disease. Nature. 2007:448:427-34.

43. Glocker $\mathrm{E}$, Grimbacher B. Inflammatory bowel disease: is it a primary immunodeficiency? Cell Mol Life Sci. 2012;69:41-8.

44. Mayer L. Evolving paradigms in the pathogenesis of IBD. J Gastroenterol. 2010;45:9-16.

45. Podolsky DK. Inflammatory bowel disease. N Engl J Med. 1991;325:928-37.

46. Hibi T, Ogata H. Novel pathophysiological concepts of inflammatory bowel disease. J Gastroenterol. 2006;41:10-6.

47. Peyrin-Biroulet $L$, Vignal $C$, Dessein $R$, Simonet $M$, Desreumaux $P$, Chamaillard M. NODs in defence: from vulnerable antimicrobial peptides to chronic inflammation. Trends Microbiol. 2006;14:432-8.

48. Shioya M, Nishida A, Yagi Y, Ogawa A, Tsujikawa T, Kim-Mitsuyama S, et al. Epithelial overexpression of interleukin-32-alpha in inflammatory bowel disease. Clin Exp Immunol. 2007;149:480-6.

49. Kobori A, Yagi Y, Imaeda H, Ban H, Bamba S, Tsujikawa T, et al. Interleukin-33 expression is specifically enhanced in inflamed mucosa of ulcerative colitis. J Gastroenterol. 2010;45:999-1007.

50. Imaeda H, Andoh A, Aomatsu T, Osaki R, Bamba S, Inatomi O, et al. A new isoform of interleukin-32 suppresses IL-8 mRNA expression in the intestinal epithelial cell line HT-29. Mol Med Rep. 2011:4:483-7.

51. Choi J, Bae S, Hong J, Ryoo S, Jhun H, Hong K, et al. Paradoxical effects of constitutive human IL-32 gamma in transgenic mice during experimental colitis. Proc Natl Acad Sci. 2010;107:21082-6.

52. Choi J-D, Bae S-Y, Hong J-W, Azam T, Dinarello CA, Her E, et al. Identification of the most active interleukin-32 isoform. Immunology. 2009;126:535-42.

53. Andoh A, Yagi Y, Shioya M, Nishida A, Tsujikawa T, Fujiyama Y. Mucosal cytokine network in inflammatory bowel disease. World J Gastroenterol. 2008;14:5154.

54. Fantini MC, Monteleone G, MacDonald TT. New players in the cytokine orchestra of inflammatory bowel disease. Inflamm Bowel Dis. 2007;13:1419-23.

55. Felaco P, Castellani ML, De Lutiis MA, Felaco M, Pandolfi F, Salini V, et al. IL-32: a newly-discovered proinflammatory cytokine. J Biol Regul Homeost Agents. 2008:23:141-7.

56. Pauwels RA, Buist AS, Calverley PM, Jenkins CR, Hurd SS. Global strategy for the diagnosis, management, and prevention of chronic obstructive pulmonary disease. NHLBI/WHO Global Initiative for Chronic Obstructive Lung Disease (COLD) Workshop summary. Am J Respir Crit Care Med. 2001;163:1256-76.
57. Lopez AD, Shibuya K, Rao C, Mathers CD, Hansell AL, Held LS, et al. Chronic obstructive pulmonary disease: current burden and future projections. Eur Respir J. 2006;27:397-412.

58. Rabe KF, Hurd S, Anzueto A, Barnes PJ, Buist SA, Calverley P, et al. Global strategy for the diagnosis, management, and prevention of chronic obstructive pulmonary disease. Am J Respir Crit Care Med. 2007; 176:532-55.

59. Luppi F, Franco F, Begh B, Fabbri LM. Treatment of chronic obstructive pulmonary disease and its comorbidities. Proc Am Thorac Soc. 2008:5:848-56.

60. Chung KF, Adcock IM. Multifaceted mechanisms in COPD: inflammation, immunity, and tissue repair and destruction. Eur Respir J. 2008;31:1334-56.

61. Gan WQ, Man SFP, Senthilselvan A, Sin DD. Association between chronic obstructive pulmonary disease and systemic inflammation: a systematic review and a meta-analysis. Thorax. 2004;59:574-80.

62. Saetta M, Di Stefano A, Turato G, Facchini FM, Corbino L, Mapp CE, et al. CD8+ T-lymphocytes in peripheral airways of smokers with chronic obstructive pulmonary disease. Am J Respir Crit Care Med. 1998;157:822-6.

63. Burrows B, Knudson RJ, Cline MG, Lebowitz MD. Quantitative relationships between cigarette smoking and ventilatory function. AM Rep. 1977;115:195-205.

64. Salvi SS, Barnes PJ. Chronic obstructive pulmonary disease in non-smokers. Lancet. 2009;374:733-43.

65. Barnes PJ. The cytokine network in chronic obstructive pulmonary disease. Am J Respir Cell Mol Biol. 2009;41:631-8.

66. Cosio MG, Saetta M, Agusti A. Immunologic aspects of chronic obstructive pulmonary disease. N Engl J Med. 2009;360:2445-54.

67. Saetta M, Mariani M, Panina-Bordignon P, Turato G, Buonsanti C, Baraldo S, et al. Increased Expression of the Chemokine Receptor CXCR3 and Its Ligand CXCL10 in peripheral airways of smokers with chronic obstructive pulmonary disease. Am J Respir Crit Care Med. 2002;165:1404-9.

68. Hogg JC, Chu F, Utokaparch S, Woods R, Elliott WM, Buzatu L, et al. The nature of small-airway obstruction in chronic obstructive pulmonary disease. N Engl J Med. 2004;350:2645-53.

69. Zhu X, Gadgil AS, Givelber R, George MP, Stoner MW, Sciurba FC, et al. Peripheral T cell functions correlate with the severity of chronic obstructive pulmonary disease. J Immunol. 2009;182:3270-7.

70. Saetta M, Turato G, Maestrelli P, Mapp CE, Fabbri LM. Cellular and structural bases of chronic obstructive pulmonary disease. Am J Respir Crit Care Med. 2001;163:1304-9.

71. Saetta M, Baraldo S, Turato G, Beghe B, Casoni GL, Bellettato CM, et al. Increased proportion of CD8+ T-lymphocytes in the paratracheal lymph nodes of smokers with mild COPD. Sarcoidosis Vasc Diffuse Lung Dis. 2003:20:28-32.

72. Bosken $\mathrm{CH}$, Hards J, Gatter K, Hogg JC. Characterization of the inflammatory reaction in the peripheral airways of cigarette smokers using immunocytochemistry. Am Rev Respir Dis. 1992;145:911-7.

73. Kouzaki H, O'Grady SM, Lawrence CB, Kita H. Proteases induce production of thymic stromal lymphopoietin by airway epithelial cells through proteaseactivated receptor-2. J Immunol. 2009;183:1427-34.

74. Proud D, Chow CW. Role of viral infections in asthma and chronic obstructive pulmonary disease. Am J Respir Cell Mol Biol. 2006;35:513-8.

75. Richter A, O'Donnell RA, Powell RM, Sanders MW, Holgate ST, Djukanovic R, et al. Autocrine ligands for the epidermal growth factor receptor mediate interleukin-8 release from bronchial epithelial cells in response to cigarette smoke. Am J Respir Cell Mol Biol. 2002;27:85-90.

76. Takizawa H, Tanaka M, Takami K, Ohtoshi T, Ito K, Satoh M, et al. Increased expression of transforming growth factor-Beta 1 in small airway epithelium from tobacco smokers and patients with chronic obstructive pulmonary disease (COPD). Am J Respir Crit Care Med. 2001;163:1476-83.

77. Ying S, O'Connor B, Ratoff J, Meng Q, Fang C, Cousins D, et al. Expression and cellular provenance of thymic stromal lymphopoietin and chemokines in patients with severe asthma and chronic obstructive pulmonary disease. J Immunol. 2008;181:2790-8.

78. Calabrese F, Baraldo S, Bazzan E, Lunardi F, Rea F, Maestrelli P, et al. IL-32, a novel proinflammatory cytokine in chronic obstructive pulmonary disease. Am J Respir Crit Care Med. 2008;178:894-901. 
79. Kudo M, Ogawa E, Kinose D, Haruna A, Takahashi T, Tanabe N, et al. Oxidative stress induced Interleukin-32 mRNA expression in human bronchial epithelial cells. Respir Res. 2012;13:19.

80. Greene CM, Low TB, O'Neill SJ, McElvaney NG. Anti-proline-glycine-proline or antielastin autoantibodies are not evident in chronic inflammatory lung disease. Am J Respir Crit Care Med. 2010;181:31-5.

Submit your next manuscript to BioMed Central and take full advantage of:

- Convenient online submission

- Thorough peer review

- No space constraints or color figure charges

- Immediate publication on acceptance

- Inclusion in PubMed, CAS, Scopus and Google Scholar

- Research which is freely available for redistribution 